\title{
MOTIVATION AMD WORKING CAPACITY OF MEDICAL WORKERSIN THE SPHERE OF PSYCHIC HEALTHCARE AS A PREDICTOR OF THEIR PSYCHOLOGICAL WELL-BEING
} Chorna V.v.

\section{МОТИВАЦІЯ I ПРАЦЕЭДАТНІСТЬ МЕДИЧНИХ ПРАЦІВНИКІВ СФЕРИ ОХОРОНИ

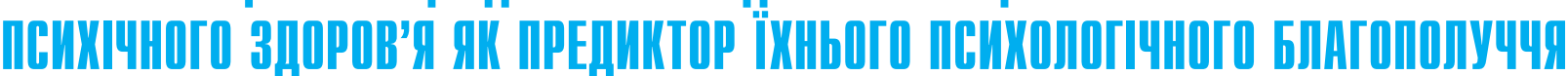

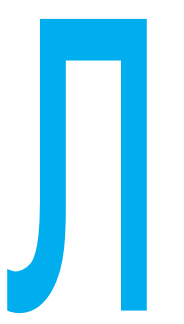

ЧOРНА В.В.

Вінницький національний медичний університет ім. М.І. Пирогова, м. Вінниця юдські ресурси, зокрема медичні ресурси закладів охорони здоров'я, з швидким економічним та інноваційним розвитком держави є одним 3 важливих важелів, що впливають на показники народжуваності, захворюваності, інвалідності, скорочення тривалості життя та смертності населення. За останні роки ці показники в Україні невпинно погіршуються, і це свідчить про глибоку кризу у сфері охорони здоров'я. Постійні реформи у ній викликають масову незадоволеність медичних працівників сфери охорони психічного здоров'я, що впливає на мотивацію і стан працездатності їх та неконтрольовану міграцію медичних працівників за кордон у пошуках достойної заробітної плати, незадоволеність населення якістю отриманої медичної допомоги у міській, а особливо у
МОТИВАЦІЯ І ПРАЦЕЗДАТНІСТЬ МЕДИЧНИХ ПРАЦІВНИКІВ СФЕРИ ОХОРОНИ ПСИХІЧНОГО ЗДОРОВ'Я ЯК ПРЕДИКТОР ЇХНЬОГО ПСИХОЛОГІЧНОГО БЛАГОПОЛУЧЧЯ Чорна В.В.

Вінницький національний медичний університет ім. М.І. Пирогова, м. Вінниця

Мета дослідження - визначення особливостей внутрішньої і зовнішньої мотивації, диференційної оцінки станів зниженої працездатності медичних працівників комунального некомерційного підприємства «Вінницька обласна клінічна психоневрологічна лікарня імені академіка О.І. Ющенка Вінницької обласної ради» і розробка профілактичних заходів.

Матеріали та методи. У дослідженні брали участь 224 медичних працівники Комунального некомерційного підприємства «Вінницька обласна клінічна психоневрологічна лікарня ім. О.І. Ющенка Вінницької обласної ради», з них 15,2\% чоловіків і 84,8\% жінок. Кількість лікарів, які взяли участь в опитуванні - 38,8\%, середнього медичного персоналу (СМП) 61,2\%. Стаж професійної діяльності лікарів становив $(19,7 \pm 12,3)$ років $і(15,5 \pm 11,1)$ років СМП. Середній вік лікарів склав $(44,6 \pm 12,2)$ років, СМП - $(37,2 \pm 11,4)$ років.

Проведено опитування щодо мотивації професійної діяльності лікарів і медичних сестер за методикою К. Замфіра у модифікації А. Реана і опитування за методикою А. Леонова, С. Величковського щодо диференційної оцінки станів зниженої працездатності (ДОСЗП) працівників закладів охорони здоров'я.

Отримані результати оброблені за допомогою ліцензійного стандартизованого пакета «Statistica 6.1 for Windows» з підрахунком середньої арифметичної величини, стандартної середньої арифметичної похибки. У роботі використовували аналіз вітчизняних і зарубіжних наукових джерел, бібліосемантічній, аналітичний і статистичний методи досліджень. Результати. У статті представлено дані опитування медичних працівників психоневрологічної лікарні щодо факторів внутрішньої та зовнішньої мотивації професійної діяльності лікарів і середнього медичного персоналу. Визначено три типи мотивації та мотиваційних комплексів у медичних працівників охорони здоров'я, використано класифікацію мотиваційних чинників: «мотиватори» $i$ «чинники контексту», або «гігієнічні фактори», які провокують негативний стрес, що впливає на якість надання медичної допомоги. Встановлено, що зовнішня негативна мотивація перевищує зовнішню позитивну у чоловіків-лікарів і у жінок СМП - (3,2 + 0,8) i $(3,0 \pm 1,2)$ бали відповідно, тому у них спостерігається зниження зацікавленості у роботі, відсутність прагнення до кар'єрного росту, відсутність самосприйняття, байдужість до роботи і пацієнтів, що може негативно впливати на якість надання медичної допомоги, на міжособистісні стосунки у колективі та вдома. Проаналізовано результати анкетування щодо диференційної оцінки станів зниженої працездатності медичних працівників психоневрологічної лікарні. Встановлено високий ступінь індексу перенасичення у жінок-лікарів (3,2\%) і жінок СПМ (1,6\%), високий ступінь втоми - 4,8\% і 3,9\% відповідно, що може оцінюватися як стан передхвороби.

Запропоновано профілактичні заходи щодо подолання цих станів і поліпшення психосоціального середовища для якісного виконання професійних обов'язків і задоволеності своєю працею.

Ключові слова: внутрішня і зовнішня мотивація, працездатність, перенасичення, стомлення, медичні працівники.

() Чорна В.В. СТАТTЯ, 2020. 
сільській місцевості. Низький рівень соціального захисту населення і недоступність медичних послуг після другого етапу медичної реформи спричинили високий рівень захворюваності порівняно 3 країнами $€ C[1,2]$. За статистичними даними ВОО3, рівень DALY (Disability-adjusted life year) років втраченого життя з поправкою на інвалідність за 2017 рік в Україні становив 34975,04 на 100 тис. населення, що вдвічі вищий порівняно з країнами Західної Європи. У структурі стандартизованих за віком втрат років життя (DALY) за 2017 рік в Україні 75,9\% припадають на втрати від неінфекційних захворювань, 15,0\% - від травм (у т.ч. насильство, конфлікти та самоушкодження), 9,1\% - на втрати від інфекційних, неонатальних, материнських і аліментарних захворювань [1, 3, 4].

Працездатність та мотивація медичного працівника тісно пов'язані з низкою чинників, а саме: заробітною платою, умовами праці і життя, розвитком кар'єри, професійним розвитком, засобами, матеріалами, медичним обладнанням. У закладах охорони здоров'я (303) необхідно покращувати психосоціальне середовище для медичних працівників з метою якісного виконання ними професійних обов'язків. Необхідна підтримка та фінансове заохочення медичних працівників з боку керівництва, зважаючи на постійне збільшення навантаження на них, високий рівень відповідальності, що призводить до стресу та вигорання на робочому місці [5-11].

I хоча наявна велика кількість наукових досліджень у цьому напрямку, проблема мотивації медичних працівників нині не вирішена. Незважаючи на очевидну економічну, соціальну, організаційну доцільність дана проблема залишається першочерговим завданням держави для подолання кризи в охороні здоров'я [12]. На жаль, багато медичних фахівців виїхало до інших країн у пошуках роботи з вищою заробітною платою.

Проблема дефіциту медичних працівників, особливо у сфері психічного здоров'я (психіатри, невропатологи, психологи), існує і в інших країнах ЄC [13-16]. Для цього європейські країни постійно вживають певні заходи: аналіз, опитування, тестування, підвищення рівня задоволеності медичних працівників і заробітної плати, використовують різні методи заохочення. В європейських країнах існує обов'язкове медичне і пенсійне страхування, тому медичні працівники мають соціальний пакет: медичне страхування, страхування від нещасних випадків, оплату професійного навчання, оплату відпочинку тощо.

Соціальний пакет у країнах ЄC має чотири складові: забезпечення здоров'я, мотивація праці, навчання, підвищення кваліфікації, соціальна підтримка, відпочинок, розваги. За кордоном основний вартісний об'єм соціального пакета до 50\% припадає на різні види страхування, але головним $€$ медичне страхування. В Україні соціальний пакет мають лише працівники великих вітчизняних компаній, які стрімко розвиваються і бажають вийти на міжнародні ринки європейських країн, де дотримуються цивілізованих принципів соціальної відповідальності за своїх працівників. Трудовим законодавством України не передбачено соціальний пакет, але існують обов'язкові страхові нарахування на заробітну плату до соціального фонду [17-21].

Великою актуальною проблемою сьогодення багатьох країн, як і України, є низька забезпеченість населення медичними працівниками у сільській місцевості. ООН оголосила пріоритетним напрямком політики багатьох країн до 2030 року розвиток забезпечення людськими/ медичними ресурсами закладів охорони здоров'я. Так, на прикладі Китаю запропоновано стратегію партнерства для громад та системи охорони здоров'я, а саме: спільне володіння та розробка програм, спільний нагляд та конструктивний зворотний зв'язок, збалансований пакет стимулів (фінансових і нефінансових), практична система моніторингу охорони здоров'я. Впроваджена стратегія партнерства для громад та системи охорони здоров'я вже декілька років дає позитивний результат $[22,23]$. Питання мотивації медичних працівників $€$ надзвичайно актуальним, тому ми присвятили свою роботу дослідженню внутрішньої та зовнішньої мотивації, працездатності медичних працівників закладів охорони здоров'я (303).

Метою роботи $€$ визначення особливостей внутрішньої і зовнішньої мотивації, диференційної оцінки станів зниженої працездатності медичних працівників Комунального некомерційного підприємства «Вінницька обласна клінічна психоневрологічна лікарня імені академіка Ющенка O.І. Вінницької обласної Ради» та розробка профілактичних заходів.

Матеріали та методи досліджень. У нашому дослідженні брали участь 224 медичні працівники Комунального некомерційного підприємства «Вінницька обласна клінічна психоневрологічна лікарня імені академіка Ющенка О.І. Вінницької обласної Ради»: $15,2 \%$ чоловіків та $84,8 \%$ жінок. В опитуванні брали участь лікарі $(38,8 \%)$ та середній медичний персонал (СМП - 61,2\%). Стаж роботи за професійною діяльністю серед лікарів становив $(19,7 \pm 12,3)$ років, $(15,5 \pm 11,1)$ років серед СМП. Середній вік серед лікарів склав $(44,6$ + $12,2)$ років, серед СМП - $(37, \overline{2}$ $+11,4)$ років.

Проведено опитування щодо мотивації професійної діяльності лікарів та медичних сестер за методикою К. Замфіра у модифікації А. Реана і опитування за методикою А. Леонова, С. Величковської щодо диференційної оцінки станів зниженої працездатності (ДОСЗП) працівників 303 $[24,25]$. 
Одержані результати оброблено за допомогою ліцензійного стандартизованого пакета «Statistica 6.1 for Windows» $з$ підрахунком середньої арифметичної величини, стандартної середньої арифметичної похибки. у роботі використовували аналіз вітчизняних та зарубіжних наукових джерел, бібліосемантичний, аналітичний та статистичний методи досліджень.

Результати дослідження та їх обговорення. У нашому дослідженні для визначення мотивації професійної медичної діяльності у медичних працівників психоневрологічної лікарні використовувалася методика «Мотивація професійної діяльності» К. Замфір у модифікації А. Реана, яка дає можливість визначити актуальність типів мотивацій: 1 - матеріальна винагорода; 2 - прагнення до кар'єрного росту; 3 - бажання не піддаватися критиці 3 боку керівництва та колег; 4 - прагнення уникати можливих покарань або неприємностей; 5 орієнтація на престиж та повагу з боку інших; 6 - задоволення від добре виконаної роботи; 7 - суспільна корисність праці. Дана методика дає змогу визначити три типи мотивації і мотиваційний комплекс медичного працівника будь-якої кваліфікації, фаху, стажу роботи: внутрішня мотивація (BM) - розуміння корисності праці, бажання навчатися і підвищувати свій професіоналізм, бути задоволеними результатами своєї трудової діяльності; зовнішня позитивна мотивація (ЗПМ) досягнення кар'єрного росту, постійна потреба у матеріальному стимулюванні, винагородах, преміях; зовнішня негативна мотивація (ЗНМ) неприємно отримувати критику, догану, штрафи від керівництва.

Медичним працівникам Вінницької обласної клінічної психоневрологічної лікарні імені академіка О.І. Ющенка було запропоновано анкету 3 запитаннями, після опитування використовувалася шкала від 1 до 5 балів: 1 бал - «дуже

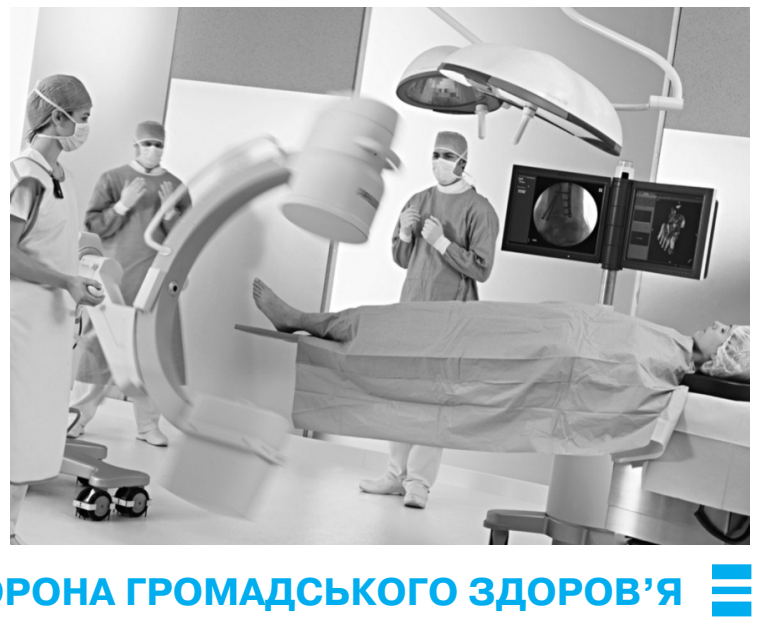

незначною мірою», 2 бали «достатньо незначною мірою». 3 бали - «не великою, але й не малою мірою», 4 бали - «досить великою мірою», 5 балів - «дуже великою мірою».

За результатами наших досліджень виявлено, що найвищий показник балів становила внутрішня мотивація в усіх медичних працівників психоневрологічної лікарні (табл. 1), яка виражалась у розумінні корисності їхньої праці, бажанні начатися і підвищувати свій професіоналізм.

Аналізуючи дані таблиці 1, можна констатувати, що у чоловіків-лікарів та у жінокСМП зовнішня негативна мотивація перевищує зовнішню позитивну $(3,2 \pm 0,8)$ і $(3,0$ \pm 1,2) бали відповідно, що відповідає мотиваційному комплексу ВМ > ЗПМ < ЗНМ. Таким чином, у цих медичних працівників можемо спостерігати зниження зацікавленості у роботі, зниження рівня психологічного благополуччя (відсутність мети у житті, негативне ставлення до інших, відсутність прагнення кар'єрного росту, відсутність самосприйняття, байдужість до роботи та інше), що може впливати негативно на якість надання медичної допомоги, на міжособистісні стосунки у колективі та вдома.

у жінок-лікарів склався мотиваційний комплекс ВМ > ЗПМ = ЗНМ. Це означає, що вони прагнуть кар'єрного росту, потребують отримувати матеріальне стимулювання, їм неприємно чути критику, отримувати догану від керівництва.

Інший мотиваційний комплекс ми отримали у чоловіків середнього медперсоналу BM > ЗПМ > ЗНМ, що підкреслює переважання розуміння корисності їхньої праці, бажання навчатися і підвищувати свій професіоналізм та прагнути кар'єрного зростання, отримуючи матеріальну винагороду, премії. Тому вони не бояться критики їхньої праці. Це - найкращий мотиваційний комплекс.

Аналізуючи результати опитування, ми скористалися класифікацією мотиваційних факторів Ф. Герцберга, за якою виділяється дві групи факторів: «мотиватори» - це чинники, які викликають позитивний вплив на мотивацію, наприклад, можливість кар'єрного росту, досягнення успіху, інтерес та задоволення роботою, самоствердження як особистості та профе-

Таблиця 1

Види мотивацій професійної діяльності у медпрацівників психіатричного 303, середнє значення (бали)

\begin{tabular}{|c|c|c|c|c|c|c|c|c|}
\hline \multirow{3}{*}{ Мотивація } & \multicolumn{4}{|c|}{ Лікарі } & \multicolumn{4}{|c|}{$\begin{array}{c}\text { Середній медичний } \\
\text { персонал }\end{array}$} \\
\hline & \multicolumn{2}{|c|}{ Чоловіки } & \multicolumn{2}{|c|}{ Жінки } & \multicolumn{2}{|c|}{ Чоловіки } & \multicolumn{2}{|c|}{ Жінки } \\
\hline & $\mathrm{M}$ & $\mathrm{m}$ & $\mathrm{M}$ & $\mathrm{m}$ & $\mathrm{M}$ & $\mathrm{m}$ & $\mathrm{M}$ & $\mathrm{m}$ \\
\hline Внутрішня & 3,9 & 0,9 & 3,6 & 0,9 & 3,9 & 1,2 & 3,3 & 0,9 \\
\hline Зовнішня позитивна & 2,9 & 0,6 & 2,7 & 0,7 & 3,4 & 1,3 & 2,8 & 0,9 \\
\hline Зовнішня негативна & 3,2 & 0,8 & 2,7 & 1,0 & 3,2 & 1,6 & 3,0 & 1,2 \\
\hline
\end{tabular}


сіонала, і «чинники контексту», або «гігієнічні чинники». Наприклад, погані умови праці та міжособистісні стосунки на роботі, низька заробітна плата та відсутність винагород, пов'язані передусім з зовнішніми умовами і зовнішньою негативною мотивацією [11, 26].

Методика диференційної оцінки станів зниженої працездатності (ДОСЗП) за А. Леоновою та С. Величковською $€$ модифікованою версією німецького тесту BMSII Пласа і Ріхтера для оцінки ступеня важкості праці за різними видами професійної діяльності. У прототипній версії методики ДОСЗП, створеній А. Леоновим та С. Величковською, виділяють чотири ступеня симптомів психічних станів: монотонія, психічне перенасичення, напруженість/стрес та стомлення. Відповіді респондентів оцінюються за допомогою чотирибальних шкал.

Монотонія - стан зниженого свідомого контролю над виконанням роботи, що виникає у ситуаціях одноманітної роботи з частим повторенням стереотипних дій і збідненим зовнішнім середовищем, супроводжується відчуттям нудьги/сонливості та домінуючою мотивацією до зміни діяльності [25].

Аналізуючи показники ступеня вираженості монотонії, який впливає на зниження працездатності працівників 303 (табл. 2), можна зробити висновок, що у жінок-лікарів помірний ступінь (від 16 до 25 балів) індексу монотонії становить $69,3 \%$ і не перевищує показники чоловіків-лікарів $(80,0 \%)$, а у жінок СМП - 78,1\% і дещо перевищує показники чоловіків СМП (77,8\%). Разом 3 тим, у жінок-лікарів та жінок СМП встановлено виражений ступінь (від 26 до 31 балів) монотонії - 9,7\% і 7,0\% відповідно, тоді як у чоловіків виражений ступінь монотонії відсутній.

Наступним критерієм, за яким оцінювалася знижена працездатність медичних працівників, було психічне перенасичення. Це стан неприйняття дуже простої і суб'єктивно нецікавої або мало усвідомленої діяльності, який проявляється у вираженому прагненні припинити роботу (відмова від діяльності) або внести різноманітність до заданого стереотипного виконання [25].
В умовах переходу України на ринкову модель недосконалість системи охорони здоров'я у частині відсутності стимулювання праці медичного людського ресурсу потребує термінових заходів удосконалення механізмів заохочення праці медичних працівників та покращання здоров'я населення України. Згідно 3 наказом МО3 України № 229 від 23.11.1993 «Про затвердження Інструкції про порядок обчислення заробітної плати працівникам охорони здоров'я та соціального захисту населення» оплата праці працівників здійснювалася пропорційно відпрацьованому часу з урахуванням доплат за роботу у нічний час, за чергування, за проведення консультації, надбавок за тривалість безперервної роботи, за складність, напруженість та високу якість роботи. Враховувались умови праці, наприклад у зв'язку з небезпечними для здоров'я та особливо тяжкими умовами праці (праця 3 психічно хворими). Оплата праці була за спеціально затвердженим Переліком (додаток № 3 - підвищення заробітної плати на 50\%). Заробіток не обмежу-

\section{Диференційна оцінка станів зниженої працездатності у медичних працівників психіатричного 303 за ступенем вираженості індексу монотонії, \%}

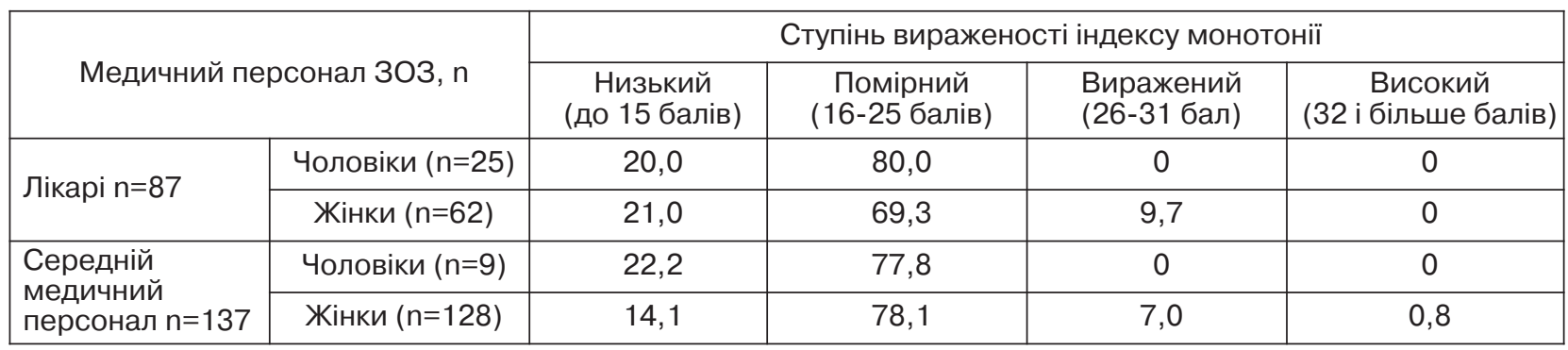

Диференційна оцінка станів зниженої працездатності медичних працівників психіатричного 303 за ступенем вираженості індексу перенасичення, \%

\begin{tabular}{|c|c|c|c|c|c|}
\hline \multirow{2}{*}{\multicolumn{2}{|c|}{ Медичний персонал 303, n }} & \multicolumn{4}{|c|}{ Ступінь вираженості індексу перенасичення } \\
\hline & & $\begin{array}{c}\text { Низький } \\
\text { (до } 15 \text { балів) }\end{array}$ & $\begin{array}{c}\text { Помірний } \\
\text { (16-25 балів) }\end{array}$ & $\begin{array}{l}\text { Виражений } \\
\text { (26-31 бал) }\end{array}$ & $\begin{array}{c}\text { Високий } \\
\text { (32 і більше балів) }\end{array}$ \\
\hline \multirow{2}{*}{ Лікарі n=87 } & Чоловіки $(\mathrm{n}=25)$ & 28,0 & 64,0 & 8,0 & 0 \\
\hline & Жінки $(n=62)$ & 30,6 & 56,5 & 8,1 & 4,8 \\
\hline \multirow{2}{*}{$\begin{array}{l}\text { Середній } \\
\text { медичний } \\
\text { персонал } \mathrm{n}=137\end{array}$} & Чоловіки $(\mathrm{n}=9)$ & 44,4 & 44,4 & 11,2 & 0 \\
\hline & Жінки $(n=128)$ & 18,8 & 64,0 & 14,1 & 2,3 \\
\hline
\end{tabular}


MOTIVATION AND WORKING CAPACITY

OF MEDICAL WORKERS IN THE SPHERE

OF PSYCHIC HEALTHCARE AS A PREDICTOR

OF THEIR PSYCHOLOGICAL WELL-BEING

\section{Chorna V.V.}

Vinnytsia National M.I. Pyrohov Medical University, Vinnytsia

Objective: We defined the internal and external motivation features, performed a differential assessment of the states of reduced working capacity in medical workers of the Vinnytsia Yushchenko O.I. Regional Clinical Psychoneurological Hospital, Vinnytsia Regional Council (Communal Non-Profit Enterprise) and developed the preventive measures.

Materials and methods: 224 medical workers (15.2\% of males and $84.8 \%$ of females) of the Clinical Psychoneurologic Hospital (Communal Non-Profit Enterprise) took part in the study. $38.8 \%$ of the doctors, $61.2 \%$ of the nurses took part in the survey. The length of service in the professional activity was $(19.7 \pm 12.3)$ years among doctors and $(15.5 \pm 11 . \overline{1})$ years among nurses. The average seniority of the doctors made up $(44.6 \pm 12.2)$ years, nurses $-(37.2 \pm$ 11.4 ) years.

We carried out a survey on the motivation of the professional activity of doctors and nurses by the methodology of $K$. Zamfir in the modification of A. Rean and a study based on the technique of A. Leonov, S. Velichkovskaya regarding the differential assessment of the states of reduced working capacity (DOSR) of workers of health care institutions.

To calculate the arithmetic mean, standard arithmetic mean error, we processed the results with the help of the Statistica 6.1 for Windows licensed standardized package. In the study, we used the analysis of the work of domestic and foreign scientific sources, biblio-semantic, analytical, and statistical research methods.

Results: The data of the survey of the psychoneurologic hospital medical workers regarding doctors' internal and external motivation and nurses' professional activity are presented in the article. Three types of motivation and the motivation complexes in healthcare workers were determined, the following classification of motivational factors were used: «motivators» and "context factors», or «hygienic factors», which provoke negative stress affecting the quality of medical care. Analysis of the survey data shows that the external negative motivation exceeds the external positive one in male doctors and female nurses $(3.2 \pm 0.8)$ and $(3.0 \pm 1.2)$ points, respectively. That's why these medical workers have a decrease in their interest in work, lack of striving for career growth, lack of self-perception, and an indifference to work, to patients, which can negatively affect the quality of medical care and interpersonal relationships the team and at home. The questionnaire results regarding the differential assessment of the states of the reduced working capacity of the psychoneurologic hospital workers have been analyzed. The results demonstrate a high level of oversaturation index in female doctors $-3.2 \%$ and female nurses $-1.6 \%$ and a high degree of fatigue $-4.8 \%$ and $3.9 \%$, respectively, which can be assessed as a pre-disease state in women.

The preventive measures to overcome these states and to improve the psychosocial environment for the quality performance of the professional duties and satisfaction with the work are proposed.

Keywords: internal and external motivation, performance, oversaturation, fatigue, medical professionals. вався граничними розмірами.

3 метою зміцнення зацікавленості працівників у зростанні продуктивності праці та підвищення рівня її нормування, якості виконуваних робіт керівники закладів охорони здоров'я могли вводити підрядну оплату праці, преміювання працівників за особистий внесок у загальні результати роботи колективу, а премії граничними розмірами не обмежувалися.

Проте Наказ Міністерства праці та соціальної політики України № 161/137 від 2001 року «Про впорядкування та затвердження умов оплати праці працівників закладів охорони здоров'я та установ соціального захисту населення» втратив чинність на підставі затвердженого нового Наказу Мінпраці, МО3 № 308/519 від 05.10.2005, який вже передба- чав підвищення заробітної плати на 25\% та 15\% за шкідливі і важкі умови праці з психічними хворими (додаток № 3). Доплати проводили за роботу у нічний час, надбавки нараховували залежно від стажу роботи та складності, напруженості, оплата здійснювалась і за чергування. 2002 року Постановою КМ України № 1298 «Про оплату праці працівників на основі Єдиної тарифної сітки розрядів і коефіцієнтів з оплати праці працівників установ, закладів та організацій окремих галузей бюджетної сфери» було введено нову форму обчислення заробітної плати працівників закладів охорони здоров'я для забезпечення законодавчо встановленого її мінімального розміру. Мінімальну зарплату та робочий час встановлено відповідно до ст. 8 Закону України від 21.12.2016 № 1801
«Про державний бюджет України на 2017 рік».

Нині змін на вторинній та третинній ланці фактично 3 нарахуванням диференційованої заробітної плати не відбулося.

Нова реформа охорони здоров'я по суті є «зрівнялівкою» і передбачає відмову від тарифних сіток розрядів і коефіцієнтів. Згідно з частиною 15 статті 16 Закону України «Основи законодавства України про охорону здоров'я» заклади охорони здоров'я, створені у результаті реорганізації державних та комунальних закладів охорони здоров'я - державних та комунальних установ, можуть мати відокремлене майно (у тому числі кошти), закріплене за ними на праві оперативного управління, самостійний баланс. 303 можуть самостійно затверджувати штат- 
ний розклад, мати рахунки в установах банків, печатки. Відповідно до частин 2 та 3 статті 94 Кодексу законів про працю розмір заробітної плати залежить від складності та умов виконуваної роботи, професійно-ділових якостей працівника, результатів його праці та господарської діяльності підприємства, установи, організації і максимальним розміром не обмежується.

Статтею 97 Кодексу законів про працю та статтею 15 Закону України «Про оплату праці» встановлено, що форми і системи оплати праці, норми праці, розцінки, тарифні сітки, ставки, схеми посадових окладів, умови запровадження та розміри надбавок, доплат, премій, винагород та інших заохочувальних, компенсаційних і гарантійних виплат встановлюються підприємствами, установами, організаціями самостійно у коллективному договорі 3 дотриманням норм і гарантій, передбачених законодавством, генеральною та галузевими (регіональними) угодами.

Зміни, внесені до статті 95 Кодексу законів про працю України та статті 3 Закону
України «Про оплату праці» у частині визначення мінімальної заробітної плати, призводять до порушення міжпосадових (міжкваліфікаційних) співвідношень у розмірі оплати кваліфікованої і некваліфікованої праці працівників бюджетної сфери. Так, згідно з нормами вищезазначених законів, працівники некваліфікованої праці (прибиральники, сторожі, двірники тощо) та висококваліфікований персонал (лікарі, медичні сестри, фельдшери та інші) отримуватимуть з урахуванням доплат і надбавок практично однакову заробітну плату.

Встановлення більш високих тарифних розрядів для медичних працівників з урахуванням професійно-кваліфікаційних вимог складності та відповідальності виконуваних робіт є надзвичайно актуальним та сприятиме забезпеченню гідної оплати праці медичних працівників, підвищенню престижності професії лікаря, збереженню кадрового медичного персоналу галузі та підвищенню якості надання медичної допомоги.

За результатами обробки та їх інтерпретації згідно з «ключем» ДОСЗП за методикою А. Леонової та С. Величков-

ської було встановлено (табл. 3), що помірний ступінь перенасичення найбільше відзначене у чоловіківлікарів і жінок СМП - 64,0\% і 64\% відповідно. Виражений ступінь (26-31 бал) психічного перенасичення (незацікавленість у роботи) встановлено у СМП жінок і чоловіків - 11,2\% і $14,1 \%$ відповідно, що пояснюється постійним їх перебуванням в умовах стаціонару та спілкуванням з хворими. Високий ступінь вираженості індексу перенасичення (32 більше балів) ми спостерігали у жінок: жінки-лікарі 4,8\%, жінки СМП - 2,3\%, оскільки жінки більш вразливі, ніж чоловіки та більш емоційно і відповідально ставляться до виконання своїх професійних обов'язків, а також дуже швидко виснажуються, що може призвести до розвитку ознак тривожного і депресивного реагування, емоційного вигорання.

Оцінювання зниженої працездатності медичних працівників проводилось за наявністю/відсутністю у них напруженості/стресу. Напруженість/стрес - стан підвищеної мобілізації психологічних і енергетичних ресурсів у медичних працівників, що

Таблиця 4

Диференційна оцінка станів зниженої працездатності медичних працівників психіатричного 303 за ступенем вираженості індексу стресу, \%

\begin{tabular}{|l|c|c|c|c|c|}
\hline \multirow{2}{*}{\multicolumn{2}{|c|}{ Медичний персонал 3О3, $n$}} & \multicolumn{4}{|c|}{ Ступінь вираженості індексу стресу } \\
\cline { 3 - 6 } & $\begin{array}{c}\text { Низький } \\
\text { (до 15 балів) }\end{array}$ & $\begin{array}{c}\text { Помірний } \\
(16-25 \text { балів) }\end{array}$ & $\begin{array}{c}\text { Виражений } \\
\text { (26-31 бал) }\end{array}$ & $\begin{array}{c}\text { Високий } \\
\text { (32 і більше балів) }\end{array}$ \\
\hline \multirow{2}{*}{ Лікарі $\mathrm{n=87}$} & Чоловіки $(\mathrm{n}=25)$ & 12,0 & 48,0 & 16,0 & 0 \\
\cline { 2 - 6 } & Жінки $(\mathrm{n}=62)$ & 11,3 & 72,6 & 12,9 & 3,2 \\
\hline $\begin{array}{l}\text { Середній } \\
\text { медичний } \\
\text { персонал } \mathrm{n=137}\end{array}$ & Чоловіки $(\mathrm{n}=9)$ & 22,2 & 66,7 & 11,1 & 0 \\
\cline { 2 - 6 } & Жінки $(\mathrm{n}=128)$ & 6,2 & 83,6 & 8,6 & 1,6 \\
\hline
\end{tabular}

Диференційна оцінка станів зниженої працездатності медичних працівників психіатричного 303 за ступенем вираженості індексу стомлення, \%

\begin{tabular}{|l|c|c|c|c|c|}
\hline \multirow{2}{*}{\multicolumn{2}{|c|}{ Медичний персонал 3О3, $n$}} & \multicolumn{4}{|c|}{ Ступінь вираженості індексу стомлення } \\
\cline { 3 - 6 } & $\begin{array}{c}\text { Низький } \\
\text { (до 15 балів) }\end{array}$ & $\begin{array}{c}\text { Помірний } \\
(16-25 \text { балів) }\end{array}$ & $\begin{array}{c}\text { Виражений } \\
\text { (26-31 бал) }\end{array}$ & $\begin{array}{c}\text { Високий } \\
\text { (32 і більше балів) }\end{array}$ \\
\hline \multirow{2}{*}{ Лікарі $\mathrm{n=87}$} & Чоловіки $(\mathrm{n}=25)$ & 24,0 & 68,0 & $8,0 \%$ & 0 \\
\cline { 2 - 6 } & Жінки $(\mathrm{n}=62)$ & 24,2 & 59,7 & 11,3 & 4,8 \\
\hline $\begin{array}{l}\text { Середній } \\
\text { медичний } \\
\text { персонал } \mathrm{n=137}\end{array}$ & Чоловіки $(\mathrm{n}=9)$ & 44,4 & 55,6 & 0 & 0 \\
\cline { 2 - 6 } & Жінки $(\mathrm{n}=128)$ & 18,0 & 66,4 & 11,7 & 3,9 \\
\hline
\end{tabular}


ОТИВАЦИЯ И РАБОТОСПОСОБНОСТЬ МЕДИЦИНСКИХ РАБОТНИКОВ СФЕРЫ ЗДРАВООХРАНЕНИЯ ПСИХИЧЕСКОГО ЗДОРОВЬЯ КАК ПРЕДИКТОР ИХ ПСИХОЛОГИЧЕСКОГО БЛАГОПОЛУЧИЯ Черная В.В.

Винницкий национальный медицинский университет им. М.И. Пирогова, Г. Винница, Украина

Цель исследования - определение особенностей внутренней и внешней мотивации, дифференциальной оценки состояний сниженной работоспособности медицинских работников Коммунального некоммерческого предприятия «Винницкая областная клиническая психоневрологическая больница имени академика О.И. Ющенко Винницкого областного совета» и разработка профилактических мероприятий.

Материалы и методы. В исследовании принимали участие 224 медицинских работника Коммунального некоммерческого предприятия «Винницкая областная клиническая психоневрологическая больница имени академика О.И. Ющенко Винницкого областного совета», из них 15,2\% мужчин и 84,8\% женщин.

Количество врачей, принявших участие в опросе - 38,8\%, среднего медицинского персонала (СМП) - 61,2\%. Стаж работы по профессиональной деятельности врачей составлял $(19,7 \pm 12,3)$ лет и $(15,5 \pm 11,1)$ лет СМП. Средний возраст врачей составил (44,6 \pm 12,2) лет, СМП - $(37,2+11,4)$ лет.

Проведен опрос относительно мотивации профессиональной деятельности врачей и медицинских сестер по методике К. Замфира в модификации А. Реана и опрос по методике A. Леонова, С. Величковской относительно дифференциальной оценки состояний сниженной работоспособности (ДОССР) работников учреждений здравоохранения.

Полученные результаты обработаны с помощью лицензионного стандартизированного пакета «Statistica 6.1 for Windows" с подсчетом средней арифметической величины, стандартной средней арифметической погрешно- сти. В работе использовали анализ отечественных и зарубежных научных источников, библиосемантический, аналитический и статистический методы исследований.

Результаты. В статье представлены данные опроса медицинских работников психоневрологической больницы относительно факторов внутренней и внешней мотивации профессиональной деятельности врачей и среднего медицинского персонала. Определены три типа мотивации и мотивационные комплексы у медицинских работников здравоохранения, использована классификация мотивационных факторов: «мотиваторы» и «факторы контекста», или «гигиенические факторы», провоцирующие негативный стресс, влияющий на качество предоставления медицинской помощи. Установлено, что внешняя негативная мотивация превышает внешнюю позитивную у мужчин-врачей и у женщин СМП - $(3,2 \pm 0,8)$ и $(3,0 \pm 1,2)$ балла соответственно, потому у них наблюдается снижение заинтересованности в работе, отсутствие стремления к карьерному росту, отсутствие самовосприятия, безразличие к работе и пациентам, что может влиять негативно на качество предоставления медицинской помощи, на межличностные отношения в коллективе и дома. Проанализированы результаты анкетирования относительно дифференциальной оценки состояний сниженной работоспособности медицинских работников психоневрологической больницы. Установлена высокая степень индекса перенасыщения у женщин-врачей (3,2\%) и женщин СПМ (1,6\%), высокая степень усталости - 4,8\% и 3,9\% соответственно, что может оцениваться как состояние предболезни.

Предложены профилактические мероприятия по преодолению этих состояний и улучшению психосоциальной среды для качественного выполнения профессиональных обязанностей и удовлетворенности своим трудом.

Ключевые слова: внутренняя и внешняя мотивация, трудоспособность, перенасыщение, усталость, медицинские работники. розвивається у відповідь на підвищення складності або суб'єктивної значущості діяльності, 3 домінуванням мотивації на подолання скрути, що реалізується у продуктивній та деструктивній формах (переважання процесуальних мотивів - мотивів самозбереження або психологічного захисту) [25].

Відповідно до даних таблиці 4 високий ступінь вираженості індексу стресу, як і у попередньому дослідженні щодо високого ступеня індексу психічного перенасичення, встановлено у жінок-лікарів $(3,2 \%)$ і жінок СПМ (1,6\%), що підтверджує наші спостереження наявного вираженого психоемоційного стану жінокмедиків у цьому закладі.

Нами здійснювалася також диференційна оцінка зниженої працездатності медичних працівників психіатричного 303 за ступенем вираженості індексу стомлення. Стомлення - це стан виснаження i дискоординації у процесі виконання основної професійної діяльності, що виникають внаслідок тривалої і інтенсивної дії робочого навантаження, $з$ домінуючою мотивацією на завершення роботи і відпочинок [25].
Відповідно до даних таблиці 5 помірний ступінь вираженості індексу стомлення спостерігався у чоловіків-лікарів - 68,0\%, на другому місці були жінки СМП - 66,40\%, на третьому місці - жінки-лікарі - 59,70\%. У цих категорій медпрацівників спостерігався виражений ступінь індексу стомлення (від 26 до 31 бала): жінки СМП - 11,7\%, жінки-лікарі - 11,3\%, чоловіки-лікарі - 8,0\%. І лише високі показники індексу стомлення (32 і більше балів) спостерігались у жінок-лікарів і жінок СМП - 4,8\% і 3,9\% відповідно, що може свідчити

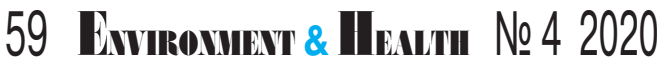


про порушення у психосоматичному і психофізіологічному стані.

Аналізом даних встановлено, що зовнішня негативна мотивація перевищує зовнішню позитивну у чоловіківлікарів та у жінок СМП - (3,2 + $0,8)$ і $(3,0 \pm 1,2)$ бали відповідно, що для здійснення професійної діяльності $€$ негативним. Необхідно правильно будувати мотивацію для здійснення медичної діяльності, зокрема формування сприятливого соціально-психологічного клімату у колективі; поширення позитивного досвіду для досягнення успіхів у роботі; забезпечення підвищення якості надання медичних послуг.

У жінок-лікарів і у жінок СМП встановлено виражений ступінь монотонії (26-31 бал) 9,7\% і 7,0\% відповідно, що означає низький рівень свідомого контролю над виконанням одноманітної роботи. Виражений ступінь (26-31 бал) психічного перенасичення, незацікавленості, байдужості до роботи встановлено у жінок СМП і чоловіків СМП $11,2 \%$ і 14,1\% відповідно, що зумовлене постійним перебуванням з хворими і потребує зміни режиму роботи цих фахівців.

Високий ступінь індексу перенасичення (32 і більше балів) встановлено у жіноклікарів $(3,2 \%)$ і жінок СПМ $(1,6 \%)$ та високий ступінь стомлення - 4,8\% і 3,9\% відповідно. Це $є$ предиктором стану передхвороби у жінок.

\section{Висновки}

3 урахуванням результатів проведеного опитування для ефективного формування позитивного мотиваційного комплексу необхідно звернути увагу на такі елементи діяльності медичних працівників:

Шзворотний зв'язок - обговорення конкретного завдання і результатів його виконання (командна робота), яку використовують в операційних;

口різноманітність вмінь та навичок - підвищення змістовності роботи, насичення її професійними, нестандарт- ними моментами, що викликає інтерес до роботи як вагомий внутрішній мотив;

口важливість роботи, яка полягає у формуванні у медичних працівників відчуття значущості і важливості своєї роботи;

口цілісність роботи, яка полягає у дорученнях медичним працівникам конкретного завдання у повному обсязі, що надасть можливість лікарям, СМП отримати задоволення від роботи;

口посилення матеріального стимулювання, а саме: скасування Постанови КМ України № 1298 від 2002 року «Про оплату праці працівників на основі Єдиної тарифної сітки розрядів і коефіцієнтів з оплати праці працівників установ, закладів та організацій окремих галузей бюджетної сфери» та усунення «зрівнялівки» в оплаті праці медичних працівників;

口впровадження обов'язкового медичного страхування та забезпечення соціальним пакетом медичних працівників.

\section{ЛІТЕРАТУРА}

1. World health statistics 2017: monitoring health for the SDGs, Sustainable

Development Goals. Geneva : WHO, 2017. 112 p.

2. Чорна В.В., Хлєстова С.С., Гуменюк Н.І.,

Махнюк В.М., Сидорчук Т.М. Показники захворюваності і поширеності та сучасні погляди на профілактику хвороб. Вісник Вінницького національного медичного університету. 2020. Т. 24, № 1. C. 158-164. Doi: 10.31393/reports-vnmedical2020-24(1)-31

3. Мезенцева Н.І.

Батиченко С.П.

Мезенцев К.В.

Захворюваність і здоров'я населення в Україні: суспільно-географічний вимір: Монографія. Київ : Принт Сервіс, 2018. 136 с.

4. Cao B., Bray F., Libawi A., Soerijomataram I. Effect on longevity of one-third reduction in premature mortality from non-communicable diseases by 2030: global analysis of the Sustainable Development Goal health target. Lancet Glob Health. 2018. Vol. 6 (12). e1288-e1296. Doi: 10.1016/S2214109X(18)30411-X

5. Головенко Х.В., Сопель О.М. Поширеність синдрому емоційного вигорання у медичного персоналу і фактори, які спричиняють його розвиток. Медсестринство. 2017. № 4. C. 51-53.

6. Драга Т.М., Мялюк О.П., Криницька І.Я. Особливості синдрому вигорання у медичних працівників. Медсестринство. 2017. № 3. C. 48-54.

7. Кастнерова М., Бабінець Л.С., Боровик О.І., Бабінець А.І. Поширеність синдрому вигорання (burnout syndrome) серед медсестер у лікарнях Південної Чехії (SOUTH BOHEMIA REGION). Здобутки клінічної і експериментальної медицини. 2017. № 3. С. 8287. doi: 10.11603/18112471.2017.v1.i3.8053

8. McFarland D.C., Hlubocky F., Susaimanickam B., O'Hanlon R., Rib M. Addressing depression, burnout, and suicide in oncology physicians. Am Soc Clin Oncol Educ Book. 2019. Vol. 39. P. 590-598. doi: 10.1200/EDBK_239087

9. Buck K., Grace A., Runyan T., Brown-Berchtoid L. Addressing mental health needs among physicians. South Med J. 2019. Vol. 112 (2). P. 67-69. doi: 10.14423/SMJ.000000000000 0924

10. Bernburg M., Vitzthum K., Groneberg D.A., Mache S. Physicians' occupational stress, depressive symptoms and work ability in relation to their working environment: a cross-sectional study of differences among medical residents with various specialties working in German hospitals. BMJ Open. 2016. Vol. 6 (6). e011369. doi: 10.1136/bmjopen-2016011369

11. Чорна В.В., Сергета І.В., Махнюк В.М. Сучасні підходи до створення внутрішньолікарняного ком- 
форту для хворих та медичного персоналу в психіатричних закладах охорони здоров'я. Biomedikal and Biosocial anthropology. 2019. Vol. 35. P. 48-53. DOI: 10.31393/bba34-2019-08

12. Orton P., Orton C., Pereira Gray D.

Depersonalised doctors: a cross-sectional study of 564 doctors, 760 consultations and 1876 patient reports in UK general practice. BMJ Open. 2012. Vol. 2 : e000274. doi: 10.1136/bmjopen-2011000274

13. Labonte R. Health in All (Foreign) Policy: challenges in achieving coherence. Health Promot Int. 2014. № 1.

P. 48-58. doi:

10.1093/heapro/dau031

14. Votruba N., Ziemann A., Grant J., Thornicroft G. A systematic review of frameworks for the interrelationships of mental health evidence and policy in low-and middleincome countries. Health Res Policy Syst. 2018. Vol. 16 (1). 85. doi: 10.1186/s12961-0180357-2

15. Sun J., Sun R., Jiang Y., Chen X., Li Z., Ma Z., Wei J., He C., Zhang L. The relationship between psychological health and social support: Evidence from physicians in China. PLoS One. 2020. Vol. 15 (1). e0228152. doi: 10.1371/journal.pone.022815 2.eCollection 2020

16. Keovathanak Khim. Are health workers motivated by income? Job motivation of Cambodian primary health workers implementing performance-based financing. Glodal Health Action. 2016. Article 31068. https://doi.org/10.3402/gha.v 9.31068

17. Malik A.A., Yamamoto S.S., Hague A., Butt N.S., Baig M. Sauerborn R. Developing and assessing a tool to measure motivation among physicians in Lahore, Pakistan. PLoS One. 2018. Vol. 13 (12). e0209546. doi: 10.1371/journal.pone.0209546. eCollection 2018

18. Liu J., Yu W., Ding T., Li M., Zhang L. Cross-sectional survey on job satisfaction and its associated factors among doctors in tertiary public hospitals in Shanghai, China. BMJ Open. 2019. Vol. 9 (3). e023823. doi: 10.1136/ bmjopen-2018-023823

19. Jiang F., Zhou H., Hu L., Rakofsky J., Liu T., Wu S., Liu H., Liu Y., Tang Y.L.

Psychiatry residents in China: socio-demographic characteristics, career satisfaction, and related factors. Front Psychiatry. 2019. № 10. 177. doi: 10.3389/fpsyt.2019.00177. eCollection 2019

20. Nantsupawat A., Kunaviktikul W., Nantsupawat R., Poghosyan L. Effects of nurse work environment on job dissatisfaction, burnout, intention to leave. Int Nurs Rev. 2017.

Vol. 64 (1). P. 91-94. doi:

10.1111/inr. 12342

21. Labrague L.J., McEnroePetitte D.M., Gloe D., Maldia F. Organizational politics, nurses' stress. Burnout levels, turnover intention and job satisfaction. Int Nurs Rev. 2017. Vol. 64 (1). P. 109-116. doi:

10.1111/inr. 12347

22. Ayalew F., Kibwana S.,

Shawula S., Misganaw E., Abosse Z. et al. Understanding job satisfaction and motivation among nurses in public health facilities of Ethiopia: a crosssectional study. BMC Nurs. 2019. Vol. 18. Article 46. doi: 10.1186/s12912-019-0373-8. eCollection 2019

23. Hu D., Zhu W., Fu Y., Zhang M., Zhao Y. et al.

Development of village doctors in China: financial compensation and health system support. Int J Eguiti Health. 2017. Vol. 16 (1). 9. doi:

10.1186/s12939-016-0505-7

24. Миронова Е.Е. Сборник психологических тестов : пособие. Ч. ІІІ. Минск :

Женский институт ЭНВИЛА, 2006. $120 \mathrm{c}$.

25. Райгородский Д.Я.

Практическая психодиагностика. Методики и тесты: уч. пособ. Самара : БАХРАХ-М, 2005. 672 c.

26. Херцберг Ф., Моснер Б., Снидерман Б.Б. Мотивация к работе. М. : Вершина, 2007. 238 с.
REFERENCES

1. World Health Statistics 2017: Monitoring Health for the SDGs, Sustainable Development Goals. Geneva : WHO ; 2017. 112 p.

2. Chorna V.V., Khliestova S.S., Humeniuk N.I. Makhniuk V.M. and Sydorchuk T.M. Pokaznyky zakhvoriuvanosti i poshyrenosti ta suchasni pohliady na profilaktyku khvorob [Incidence and Prevalence Rates and Current Views on Diseases'

Prevention]. Visnyk

Vinnytskoho natsionalnoho medychnoho universytetu. 2020 ; 24 (1) : 158-164. Doi: 10.31393/reports-vnmedical2020-24 (1)-31 (in Ukrainian).

3. Mezentseva N.I.,

Batychenko S.P. and

Mezentsev K.V.

Zakhvoriuvanist i zdorovia naselennia v Ukraini: suspilnoheohrafichnyi vymir:

Monohrafiia [Morbidity and Health of the Population in Ukraine: Socio-Geographical Dimension: Monograph]. Kyiv : Print Servis ; 2018 : 136 p. (in Ukrainian).

4. Cao B., Bray F., Libawi A. and Soerijomataram I. Effect on Longevity of One-Third Reduction in Premature Mortality from NonCommunicable Diseases by 2030: Global Analysis of the Sustainable Development Goal Health Target. Lancet Glob Health. 2018 ; 6 (12) : e1288e1296. Doi: 10.1016/S2214109X(18)30411-X

5. Holovenko Kh.V. and Sopel O.M. Poshyrenist syndromu emotsiinoho vyhorannia u medychnoho personalu i faktory, yaki sprychyniaiut yoho rozvytok [The Prevalence of Emotional Burnout in Medical Staff and the Factors that Cause its Development]. Medsestrynstvo. 2017; 4 : 51 53 (in Ukrainian).

6. Draha T.M., Mialiuk O.P. and Krynytska I.Ya. Osoblyvosti syndromu vyhorannia u medychnykh pratsivnykiv [Features of Burnout Syndrome in Medical Professionals]. Medsestrynstvo. 2017 ; 3 : 4854 (in Ukrainian).

7. Kastnerova M., Babinets L.S., Borovyk O.I. and 
Babinets A.I. Poshyrenist syndromu vyhorannia (burnoutsyndrome) sered medsester $u$ likarniakh Pivdennoi Chekhii (SOUTH BOHEMIA REGION) [Prevalence of Burnout Syndrome among Nurses in Hospitals in South Bohemia (SOUTH BOHEMIA REGION]. Zdobutky klinichnoi i eksperymentalnoi medytsyny. 2017 ; 3 : 82-87. doi: 10.11603/18112471.2017.v1.i3.8053

(in Ukrainian).

8. McFarland D.C., Hlubocky F., Susaimanickam B., O'Hanlon R. and Riba M. Addressing Depression, Burnout, and Suicide in Oncology Physicians. Am Soc Clin Oncol Educ Book. 2019 ; 39 : 590-598. doi:

10.1200/EDBK_239087

9. Buck K., Grace A. Runyan T. and BrownBerchtoid L. Addressing Mental Health Needs among Physicians. South Med J. 2019 ; 112 (2) : 67-69. doi: $10.14423 /$ SMJ.000000000000 0924

10. Bernburg M.,

Vitzthum K., Groneberg D.A. and Mache S. Physicians' Occupational Stress,

Depressive Symptoms and Work Ability in Relation to their Working Environment: a CrossSectional Study of Differences among Medical Residents with Various Specialties Working in German Hospitals. BMJ Open. 2016 ; (6) : e011369. doi: 10.1136/bmjopen-2016011369

11. Chorna V.V., Serheta I.V. and Makhniuk V.M. Suchasni pidkhody do stvorennia vnutrishnolikarnianoho komfortu dlia khvorykh ta medychnoho personal v psykhiatrychnykh zakladakh okhorony zdorovia [Modern Approaches to the Creation of In-Hospital Comfort for Patients and Medical Staff in Psychiatric Health Care Facilities]. Biomedical and Biosocial Anthropology. 2019 ; 35 : 4853. DOI: $10.31393 /$ bba342019-08 (in Ukrainian).

12. Orton P., Orton C. and Pereira Gray D. Depersonalised Doctors: a Cross-Sectional Study of 564 Doctors, 760 Consultations and 1876 Patient Reports in

UK General Practice. BMJ Open. 2012 ; 2: e000274. doi: 10.1136/bmjopen-2011 000274

13. Labonte R. Health in All (Foreign) Policy: Challenges in Achieving Coherence. Health Promot Int. 2014 ; 1 : i48-58. doi: $10.1093 /$ heapro/dau031

14. Votruba N., Ziemann A., Grant J. and Thornicroft G. A Systematic Review of

Frameworks for the Interrelationships of Mental Health Evidence and Policy in Low-and Middle-Income Countries. Health Res Policy Syst. 2018 ; 16 (1) : 85. doi: 10.1186/s12961-018-0357-2

15. Sun J., Sun R., Jiang Y., Chen X., Li Z., Ma Z., Wei J., He C. and Zhang L. The

Relationship between

Psychological Health and Social Support: Evidence from Physicians in China. PLoS One. 2020 ; 15 (1) : e0228152. doi: 10.1371 /journal.pone.0228152.eCollection 2020

16. Keovathanak Khim. Are Health Workers Motivated by Income? Job Motivation of Cambodian Primary Health Workers Implementing

Performance-Based

Financing. Glodal Health Action. 2016 ; Article 31068. https://doi.org/10.3402/gha.v 9.31068

17. Malik A.A., Yamamoto S.S., Hague A., Butt N.S., Baig M. and Sauerborn R. Developing and Assessing a Tool to Measure Motivation among Physicians in Lahore, Pakistan. PLoS One. $2018 ; 13$ (12) : e0209546. doi:10.1371/journal.pone.020 9546. eCollection 2018

18. Liu J., Yu W., Ding T., Li M. and Zhang L. CrossSectional Survey on Job Satisfaction and its Associated Factors among Doctors in Tertiary Public Hospitals in Shanghai, China. BMJ Open. 2019 ; 9 (3) : e023823. doi: 10.1136/bmjopen-2018023823

19. Jiang F., Zhou H., Hu L., Rakofsky J., Liu T., Wu S., Liu H., Liu Y. and Tang Y.L. Psychiatry Residents in China: Socio-Demographic
Characteristics, Career Satisfaction, and Related Factors. Front Psychiatry. 2019 ; 10 : 177. doi: 10.3389/fpsyt.2019.00177. eCollection 2019

20. Nantsupawat A., Kunaviktikul W., Nantsupawat R. and Poghosyan L. Effects of Nurse Work Environment on Job Dissatisfaction, Burnout, Intention to Leave. Int Nurs Rev. 2017 ; 6 (1) : 91-94. doi: 10.1111/inr.12342

21. Labrague L.J., McEnroePetitte D.M., Gloe D. and Maldia F. Organizational Politics, Nurses' Stress. Burnout Levels, Turnover Intention and Job Satisfaction. Int Nurs Rev. 2017 ; 64 (1) : 109-116. doi:

10.1111/inr. 12347

22. Ayalew F., Kibwana S., Shawula S., Misganaw E., Abosse Z. et al. Understanding Job Satisfaction and Motivation among Nurses in Public Health Facilities of Ethiopia: a Cross-Sectional Study. BMC Nurs. 2019 ; 18. Article 46. doi: 10.1186/s12912-019-0373-8. eCollection 2019

23. Hu D., Zhu W., Fu Y., Zhang M., Zhao Y. et al. Development of Village Doctors in China: Financial Compensation and Health System Support. Int J Eguiti Health. 2017 ; 16 (1) : 9. doi: 10.1186/s12939-016-0505-7

24. Mironova E.E. Sbornik psikhologicheskikh testov : posobiye. Chast 3 [Collection of Psychological Tests:

Manual. Part 3]. Minsk : Zhenskiy institute ENVILA ; 2006 ; 120 p.

(in Russian).

25. Raygorodskiy D.Ya.

Prakticheskaya psikhodiagnostika. Metodiki I testy: uchebnoye posobiye [Practical Psychodiagnosis. Techniques and Tests: Study Guide]. Samara : BAKhRAKh-M ; 2005 : 672 p. (in Russian).

26. Khertsberg F., Mocner B. and Sniderman B.B.

Motivatsiya k rabote

[Motivation to Work]. Moscow : Vershina ; 2007 : 238 p.

(in Russian).

Надійшло до редакції 14.06.2020 